\title{
A Sonata do Girassol Vermelho: contribuições para a literatura musical para viola
}

\author{
Semitha Heloisa Matos Cevallos \\ Pesquisadora independente \\ spianista@hotmail.com \\ https://orcid.org/0000-0001-9325-9430
}

Resumo: A Sonata do Girassol Vermelho (2019), objeto deste estudo, é a obra mais recente para viola e piano do compositor brasileiro Harry Crowl. Para melhor compreender o lugar que a viola ocupou na história da música, o artigo faz um recorte histórico que tem início no final do séc. XIX/início do XX, quando violistas de países europeus, assim como a Rússia, apresentaram aspirações comuns de tirar a viola de sua, até então, posição de importância secundária, grande parte em razão do pequeno número de solistas em atuação e pouco ou quase nenhum repertório específico para o instrumento. Durante o séc. XX, esse cenário foi modificando-se e os compositores brasileiros passaram a apresentar obras de contribuição significativa para o repertório de viola.

Palavras-chave: Harry Crowl, Viola, Sonata do Girassol Vermelho, Música Contemporânea Brasileira, Música de Câmara Brasileira.

\section{The Red Sunflower Sonata: contributions to the viola musical literature}

\begin{abstract}
The Red Sunflower Sonata (2019), object of this study, is the most recent work for viola and piano by Brazilian composer Harry Crowl. In order to better understand the place that the viola played in the history of music, this article makes a historical outline that begins at the end of the $19^{\text {th }}$ century/ beginning of the $20^{\text {th }}$, when violists from European countries, as well as Russia, presented common aspirations to remove the viola from its, until then, position of secondary importance, that it had occupied until then, largely due to the small number of active soloists and little or almost no specific repertoire for the instrument. During the XX century, this scenario changed, and Brazilian composers also started to present works of significant contribution to the viola repertoire.
\end{abstract}

Keywords: Harry Crowl, Viola, Red Sunflower Sonata, Brazilian Contemporary Music, Brazilian Chamber Music.

\section{Introdução}

A Sonata do Girassol Vermelho (2019), objeto deste estudo, é a obra mais recente para viola e piano do compositor brasileiro Harry Crowl. Para melhor compreender o lugar que a viola ocupou na história da música, o artigo faz um recorte histórico que tem início no final do séc. XIX/início do XX, quando violistas de países europeus, assim como da Rússia, apresentaram aspirações comuns de tirar a viola de sua, até então, posição de importância secundária, grande parte em razão do pequeno número de solistas em atuação e pouco ou quase nenhum repertório específico para o instrumento. Durante o séc. XX, esse cenário foi modificando-se e os compositores brasileiros passaram a apresentar obras de contribuição significativa para o repertório de viola. 


\title{
$O$ despertar da viola como instrumento solista
}

Por séculos, a viola foi um instrumento no qual os violinistas revezavam-se ao fazer música de câmara. Os músicos que continuavam tocando o instrumento, ou tinham interesse por ele, mantinham-se em uma situação de inferioridade em relação ao violino. Na Alemanha, eram chamados de Penzioninstrument, ou seja, instrumento de aposentado, designado para violinistas idosos que já não possuíam técnica apurada ou a alguém que não tinha o talento suficiente para tocar violino profissionalmente (PRIMROSE, 1978, p. 19). Contudo, no final do séc. XIX, vários violistas levantaram-se contra esse tipo de postura preconceituosa em relação à viola e, através de um sério trabalho de execução e ensino, iniciaram uma mudança de atitude e pensamento, elevando o status do instrumento.

Não havia, até o final do séc. XIX, solistas na viola. Um dos primeiros, ou quem sabe, o primeiro violista de fama internacional foi o inglês Lionel Tertis (1876-1975), considerado o pai da Escola Inglesa de Viola. Sua atividade artística e pedagógica abriu a possibilidade para que outros músicos desse instrumento também seguissem carreira como solistas, algo sem precedentes até aquele momento. "Tertis e Casals ${ }^{1}$ foram os primeiros intérpretes nos seus respectivos instrumentos a serem comparados favoravelmente aos grandes virtuoses do violino e piano" (RILEY, 1980, p. 252, tradução nossa).

O instrumentista Tertis deu significativa contribuição para a expansão do repertório de viola ao encorajar compositores a escrever para ele. Muitas dessas peças não eram obras-primas e, após apresentá-las em público, ele as usava como obras didáticas a fim de que seus alunos tivessem a oportunidade de ter contato com uma literatura recémescrita.

\begin{abstract}
A lista de compositores que escreveram obras para Tertis é impressionante. Incluem: Arnold Bax, Stanley Bate, W. H. Bell, Arthur Benjamin, Arthur Bliss, York Bowen, Benjamin Dale, T. F. Dunhill, H. Farjeon, Gustav Holst, John McEwen, Richard L. Malthew, William Reed, Cyril Scott, William Walton, Ralph Vaughn Williams, e Waldo Warner (RILEY, 1980, p. 248, tradução nossa).
\end{abstract}

Do início do séc. XX até o começo da Segunda Guerra Mundial, a viola cresceu muito em importância na Inglaterra devido à intensa atuação de Tertis. Percebia-se a

\footnotetext{
${ }^{1}$ Pablo Casals (1876-1973), foi um virtuoso violoncelista espanhol.
} 
maior aceitação do instrumento por parte de compositores e regentes, pois havia maiores oportunidades de execução, além do crescente interesse pelo estudo do instrumento. Nos anos pós-guerra, outro violista surgiria na Inglaterra, William Primrose (1904-1982), que será abordado mais adiante.

O repertório orquestral do final do séc. XIX tinha aumentado muito as exigências técnicas para as partes de viola e o nível técnico insuficiente de execução desses instrumentistas vinha preocupando as instituições de ensino musical na Europa. Por esse motivo, o Conservatório de Paris instituiu, em 1894, o programa de viola - 99 anos após implementar os programas de violino e violoncelo. Théofile Laforge (1863-1918) foi o primeiro professor de viola da instituição, ensinando por 24 anos. Sua atuação pedagógica elevou o nível técnico do instrumento e criou uma nova geração de violistas. Maurice Vieux (1884-1951), aluno de Laforge, assumiu a Cátedra de viola, após a morte do seu professor. Seguiu no caminho do mestre, continuando a perseguir elevados níveis de ensino em técnica e execução.

Hermann Ritter (1849-1926) foi o nome mais importante para a viola na segunda metade do sec. XIX na Alemanha. “... virtuoso alemão, [...] impressionou maestros e compositores alemães pelo seu talento artístico e dedicação para com a viola, sendo pioneiro no uso de sua viola alta, modelo grande" (RILEY, 1980, p. 241, tradução nossa). Depois da Segunda Guerra, mais uma nova geração de violistas surgiu no país, assim como de compositores que escreveram para o instrumento. Uma das contribuições mais significativas foi a do compositor e violista Paul Hindemith (1895-1963) com mais de vinte obras específicas para o instrumento.

Na Rússia, o pioneiro na valorização da viola foi Vladmir Bakaleinikoff (18851953), que ensinou nos Conservatórios de São Petesburgo (1918-1920) e Moscou (19201924). Tendo partido para os Estados Unidos, seu aluno Vadim Borisovsky (1900-1972), o sucedeu, estabelecendo a escola soviética de viola, onde ensinou por volta de 200 violistas que estiveram em posições de liderança nas orquestras da época.

Nos anos pós-guerra e durante a segunda metade do séc. XX, o inglês William Primrose foi mundialmente o nome mais importante da viola. "Assim como os nomes Kreisler e Heifetz tinham se tornado sinônimo da palavra violino, o nome Primrose se tornou sinônimo da palavra viola" (RILEY, 1980, p. 283, tradução nossa). Além de sua 
atuação como intérprete que o levou à fama internacional, outra contribuição relevante para o universo da viola foi sua visão em relação ao instrumento. O músico tinha um olhar diferente da viola: não a via como um violino maior, mas como um instrumento independente e separado. E a literatura de violino, bem como a forma tradicional de tocálo que havia permeado o mundo da viola por muito tempo foram questionadas e postas de lado por Primrose, que de forma própria e em respeito ao instrumento, empregava dedilhados e arcadas distintas das utilizadas para tocar violino.

Como é possível notar, é quase como se fosse um movimento - obviamente não coordenado -, motivado pelo desejo de violistas em valorizar a viola. Aliado a isso, algo recorrente nesse processo era a encomenda de obras por parte dos violistas aos compositores, já que o repertório para o instrumento era escasso. Através dessa prática, que continua até hoje, mais obras foram escritas para viola durante todo o séc. XX, aumentando a gama de composições originais. Dentro desse panorama, os compositores brasileiros apresentam obras que enriquecem o repertório de viola e contribuem para o fortalecimento de sua identidade.

\section{Obras brasileiras para viola como instrumento solista}

As obras brasileiras que têm a viola como protagonista datam da segunda metade do séc. XX. O surgimento dessas composições coincide com a chegada ao Brasil de três violistas húngaros: Bela Mori (1912-2006), Perez Dworecki (1920-2011) e George Kiszely (1930-2010) ${ }^{2}$, vindos como imigrantes no final dos anos 1940. A pesquisadora Hellen Mizael comenta em sua dissertação sobre o ambiente musical referente à viola na primeira metade do séc. XX:

Pode-se destacar que na primeira metade do século $\mathrm{XX}$, a viola era raramente tratada como instrumento solista no Brasil devido: 1) à falta de intérpretes; 2) à carência de ensino focado especificamente para a técnica do instrumento; 3) e à existência de um limitado repertório (MIZAEL, 2011, p. 17-18).

\footnotetext{
${ }^{2}$ São quase inexistentes os estudos sobre a biografia destes três violistas húngaros que foram cruciais para o desenvolvimento da viola no Brasil, bem como sobre o violista uruguaio Gualberto Estades Basabilbaso. Somente o trabalho de mestrado de Hellen Dias Mizael sobre a Sonata para viola e piano de Guarnieri, apresenta em suas primeiras páginas uma pequena biografia sobre Dworecki, sem fazer uma análise mais profunda sobre sua vinda ao Brasil e sua permanência no país. Os outros três instrumentistas mencionados ainda carecem de pesquisa.
} 
O cenário brasileiro anterior à vinda desses três instrumentistas era o mesmo que na Europa no final do séc. XIX. Ou seja, a viola era utilizada somente em formações orquestrais e quarteto de cordas, não havia solistas do instrumento, nem atuação pedagógica específica para a viola e ausência de repertório. Contudo, a atuação desses três instrumentistas impulsionou a criação de repertório para a viola, surgindo assim muitas composições dedicadas a eles.

Para este estudo, foi feito um levantamento no qual a viola atua como instrumento solista nas seguintes formações: viola solo, viola e piano, viola e orquestra, duo de violas, viola e sons eletrônicos. Esta pesquisa foi realizada junto à ABRAV (Associação Brasileira de Violistas), utilizando-se também catálogos disponíveis, acervos digitais e contato direito com os compositores. Foram listadas 129 obras de 69 compositores e compositoras, organizadas por data de composição. Essa relação, que não pretende enumerar todas as obras do repertório musical brasileiro para viola, é certamente uma lista parcial, mas que apresenta um amplo panorama da criação dos compositores brasileiros para o instrumento (ver apêndice).

Ao analisar esse material temos a percepção de vários aspectos da música de concerto para viola. A primeira delas é a ainda pequena presença de compositoras. Figuram na lista oito delas: Lycia de Biase Bidart (1910-1990), com duas obras para viola: O lago-fantasia para viola e piano (1965) e Serenata para viola e piano (1974); Jocy de Oliveira (1936), com uma obra: Enceladus para viola solo (2019); Marisa Rezende (1944), também com uma obra: Diálogos para viola solo (2019); Ilza Nogueira (1948), com a composição: Brasil, 1959 para viola e piano; Silvia de Lucca (1960), com a peça: Verge para viola solo (2019); Lourdes Saraiva (1966), com uma obra: Poem to an Ancient Tree para viola solo (2016); Tatiana Catanzaro (1976), com uma obra: Intarsia para viola e sons eletrônicos (2011/2012); Valéria Bonafé (1984) também com uma obra: Estudos sobre os estados da matéria para viola solo (2012).

É possível perceber também que a grande maioria dos compositores e compositoras escreveu somente uma obra para viola, constatando-se que a produção para viola ainda é pequena em comparação com a quantidade de composições escritas para outros instrumentos, principalmente o violino. Um desses exemplos é o compositor Camargo Guarnieri (1907-1993) que apresenta somente duas peças para viola: Sonata para viola e 
piano (1950) e Choro para viola e orquestra (1975) - em contraste com as sete sonatas para violino e piano que escreveu - sendo que a primeira delas perdeu-se. O mesmo ocorre com Almeida Prado (1943-2010), que compôs somente uma Sonata para viola e piano (1983) em comparação com as quatro sonatas para violino e piano.

O compositor Claudio Santoro (1919-1989) apresenta, junto com o compositor Harry Crowl, o maior número de obras para viola, num total de oito peças cada um. Contudo, a primeira dessas obras, que data de 1943, e que teria sido a primeira sonata para viola e piano da música brasileira, não foi concluída, de acordo com o catálogo de obras de Santoro. Ao consultar o filho do compositor, Alessandro Santoro, ele traz novas informações sobre a peça:

\begin{abstract}
Consta no catálogo, (porque muitas informações foram trazidas de catálogos anteriores) como inacabada, mas na verdade ela se encontra perdida no momento. Algumas obras inacabadas do período dodecafônico, papai terminou na Alemanha mesmo, até por insistência da minha mãe. Mas algumas ficaram perdidas, algumas foram recuperadas. É isso que posso dizer infelizmente, mas sem dedicatória e nem algum esboço, não tenho como saber mais sobre a obra no momento, isso me dói muito no coração, mas me conforta que na época que papai faleceu, no acervo dele se encontravam quase 80 músicas desaparecidas e agora são menos de 20 (SANTORO, 2020).
\end{abstract}

Nesse caso, são sete as obras para viola de Claudio Santoro, já que a sonata de 1943 encontra-se perdida. Com base nessas informações, uma das primeiras obras dentro da música brasileira que coloca a viola como instrumento solista é a Sonata para viola e piano (1950), de Camargo Guarnieri, dedicada a Perez Dworecki (Fig. 1). 
Figura 1 - C. Guarnieri: Excerto da Sonata para viola e piano (c. 1-10).

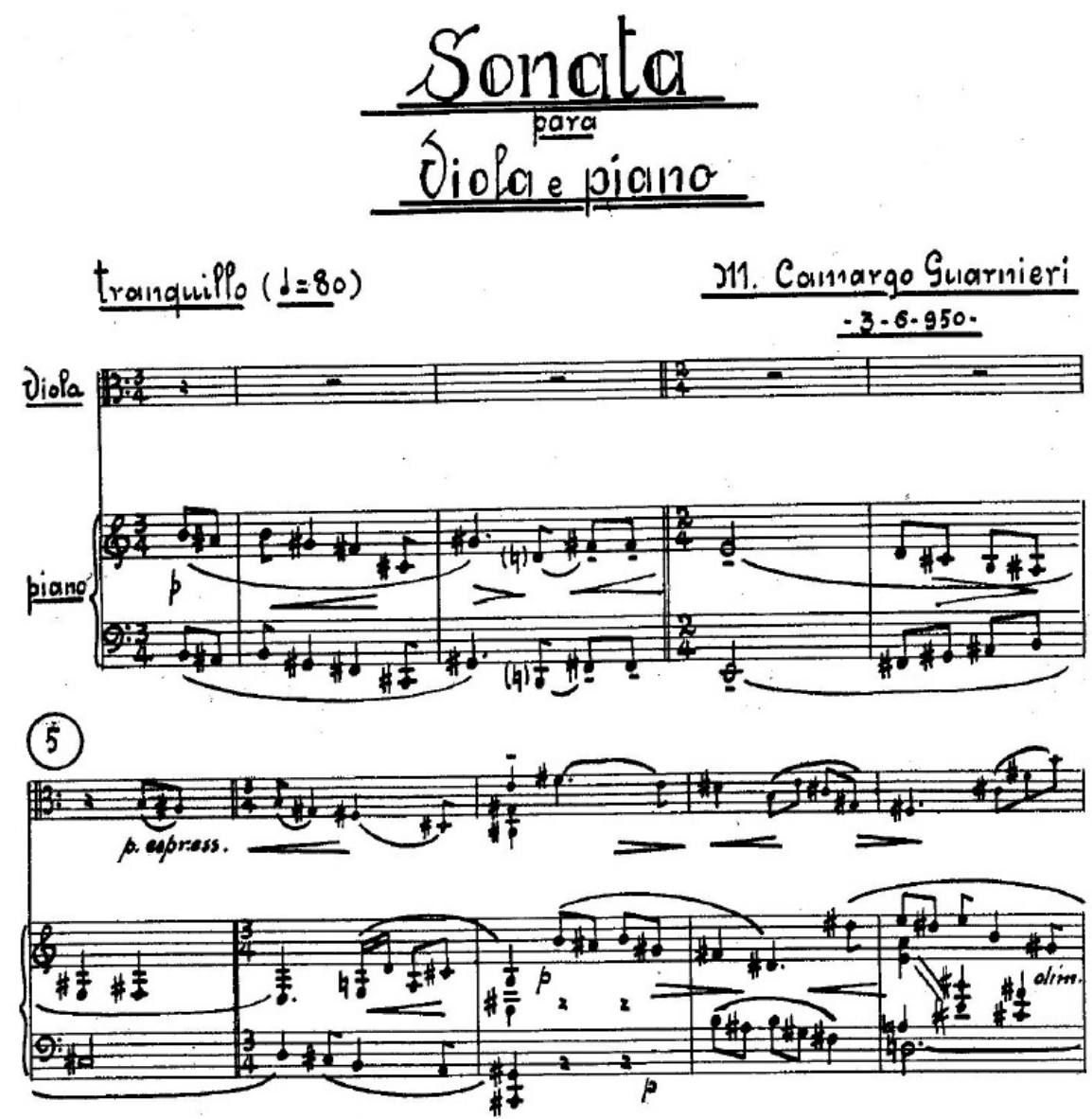

Fonte: GUARNIERI, Camargo. Sonata para viola e piano. São Paulo: manuscrito, 1950. Viola e piano. Arquivo pessoal da autora.

Dworecki havia estudado violino e viola em Budapeste no Conservatório Franz Liszt, tendo sido aluno de importantes figuras da cena musical daquele país: Léo Weiner (1885-1960), Zoltán Kodály (1882-1967) e Sándor Végh (1912-1997). “Com os acontecimentos da II Guerra Mundial o violista refugiou-se no Brasil em 1947. Com pouco tempo de permanência no país ele foi contratado para ser o primeiro violista da Orquestra Sinfônica do Teatro Municipal de São Paulo.” (MIZAEL, 2011, p. 19).

Foi nesse contexto que Dworecki conheceu Guarnieri, que havia assumido o cargo de regente supervisor da orquestra. Em entrevista à pesquisadora Hellen Mizael, Dworecki comenta sobre como surgiu a Sonata:

Não encomendei a Sonata, apenas sugeri que Guarnieri escrevesse algo para viola. Eu disse a ele: - "Você já escreveu peças para violino e violoncelo, e ainda não escreveu nada para viola, por que você não escreve algo para viola?". Um tempo depois, ele aparece com a Sonata e logo começamos a ensaiar (DWORECKI, 2010 apud MIZAEL, 2011, p.20). 
Através dos três movimentos da sonata, o compositor utiliza ritmos irregulares, com ênfase nas síncopes, acentos deslocados, influência das danças indígenas e nordestinas, como, por exemplo, o baião. Faz uso de semicolcheias em alusão ao choro, emprega temas melódicos e uma rítmica que lembram as marchinhas de carnaval. Essa linguagem não era familiar a Dworecki, que comenta não ter gostado de sua primeira execução junto ao compositor:

Ele era um compositor muito criterioso, quando tocamos a Sonata pela primeira vez na rádio, ele não gostou de sua performance e eu não gostei da minha. Eu ainda não estava acostumado com a linguagem [musical] dele, uma linguagem muito individual e ao mesmo tempo brasileira. Guarnieri contribuiu não somente para a evolução da técnica da viola, mas também para a evolução da música brasileira (DWORECKI, 2010 apud MIZAEL, 2011, p. 21).

A Sonata para e viola e piano de Guarnieri é uma obra de viés nacionalista e através dela é possível perceber o compromisso do compositor com suas ideias, que seriam expressas cinco meses após a composição da Sonata por meio da Carta Aberta aos Músicos e Críticos do Brasil (07/11/1950), em que ele atribui ao dodecafonismo o objetivo de destruição do caráter nacional. É, igualmente, uma obra marco na história da viola no Brasil por apresentar o instrumento em posição de solista e colocá-lo em um nível de igualdade técnico-musical com o violino. É uma pena que o compositor não tenha se dedicado a compor mais obras para a viola.

Outra obra significativa para este estudo é a Sonata para viola e piano (1983), do compositor Almeida Prado, pois foi ela a inspiração de Harry Crowl para compor a Sonata do Girassol Vermelho. A peça constitui-se de três movimentos: Allegro, Interlúdio Onírico e Variações sobre um coral de Bach no qual figuram três variações e um epílogo. Foi escrita em homenagem ao $3^{\circ}$ centenário de nascimento de J. S. Bach (1685-1985) e dedicada ao violista Gualberto Estades Basavilbaso (Fig. 2). 
Figura 2 - Almeida Prado: Excerto do terceiro movimento da Sonata para viola e piano (c. 1-9). Apresentação do tema em sol menor e variação I.

Variações sobre um choral de J.S. Bach

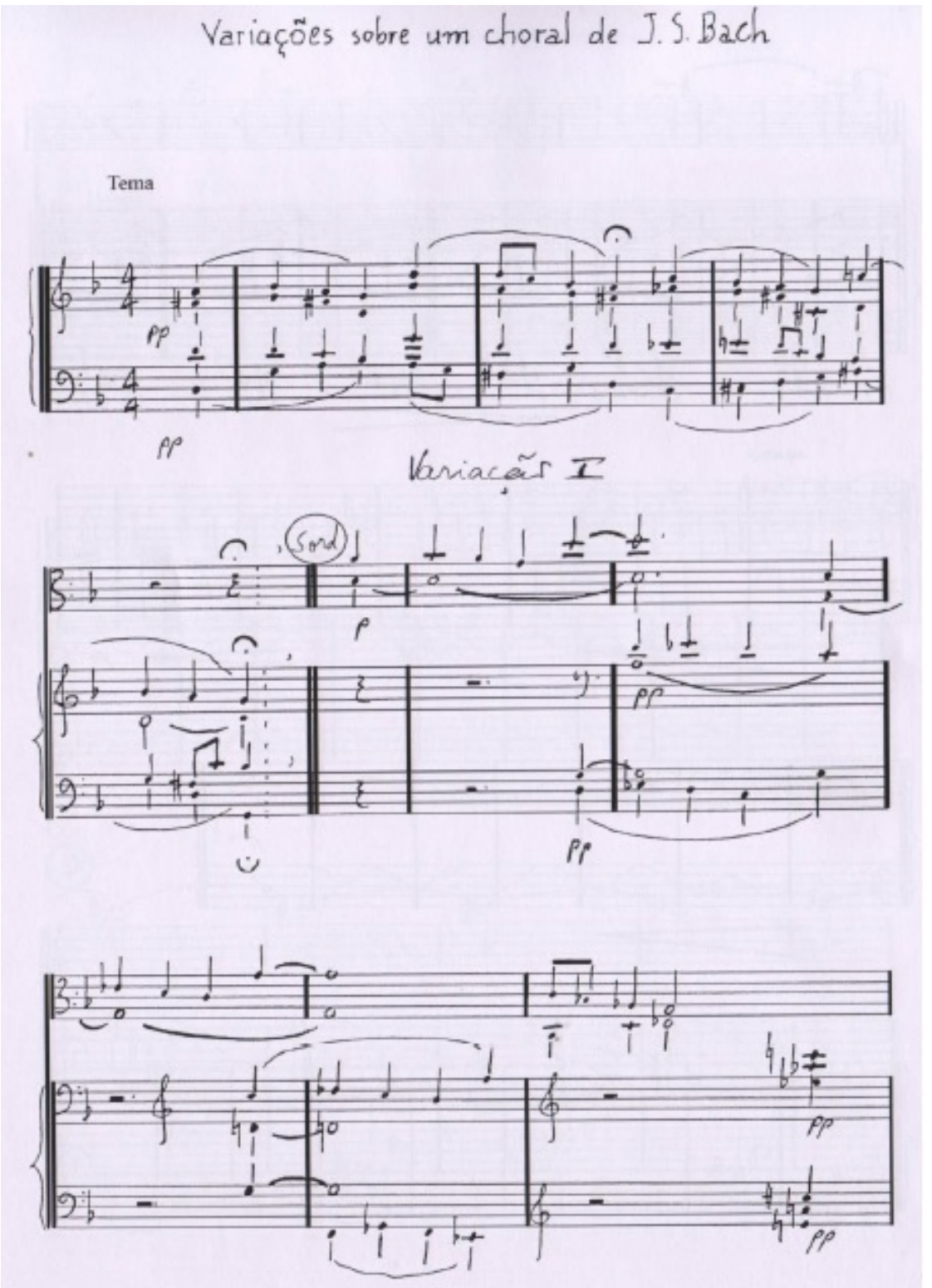

Fonte: PRADO, Almeida. Sonata para viola e piano. Rio de Janeiro: Academia Brasileira de Música Banco de Partituras de Música Brasileira, 2011. Viola e piano.

Estades foi um violista uruguaio radicado no Brasil que teve atuação artísticopedagógica em Salvador, Porto Alegre e Campinas. Foi violista da Orquestra Sinfônica Municipal de Campinas (OSMC), tendo ingressando posteriormente na UNICAMP como docente, onde aposentou-se como Professor Titular Doutor. Dedicava-se à pesquisa de música contemporânea, e teve muitas obras dedicadas a ele.

Certamente, foi no ambiente acadêmico que Almeida Prado e Estades conheceram-se e, possivelmente, pensaram na composição da Sonata para viola e piano. 
Curiosamente, neste mesmo ano (1983), Raul do Valle (1936), também seu colega na UNICAMP, escreveu uma obra dedicada a ele: Alternância para viola e orquestra de cordas (1983). Essa obra foi estreada por Estades, juntamente com a seção de cordas da Orquestra Sinfônica do Estado de São Paulo, sob a regência do próprio compositor no Teatro São Pedro, em São Paulo (VALLE, 2016, p. 15).

Analisando a Sonata para viola e piano, Almeida Prado utiliza, no primeiro movimento técnica estendida com o emprego dos harmônicos da viola, além de uma rítmica irregular com acentos deslocados, colcheias, semicolcheias e appogiaturas. Contudo, sem fazer qualquer alusão ao folclore ou danças brasileiras, o material composicional é empregado dentro de uma linguagem atonal livre, pós-Schoenberg.

O segundo movimento, o mais curto, tem a duração de pouco mais de um minuto. Nele, o compositor faz uma expansão sonora na viola com o uso de cromatismos, glissandos e trinados. Ademais utiliza de tríades maiores na mão esquerda do piano e notas cromáticas na direita. Isso faz com que o piano gere muitos harmônicos em suspensão que vão confundindo-se com os sons da viola. Esse movimento - Interlúdio Onírico - está relacionado ao universo dos sonhos pela dramaticidade que causam os efeitos empregados por Almeida Prado, como sugere o título. Durante a escuta da obra, o ouvinte pode sentir um choque com o que vem em seguida, ou seja, o terceiro movimento, quando pela primeira vez se ouve o material composicional em linguagem tonal. O coral de Bach é apresentado no início do terceiro movimento em sol menor. Todavia, ao longo das três variações, o compositor emprega a tonalidade de forma expandida.

Ao comparar as sonatas para violino e piano de Almeida Prado com sua Sonata para viola e piano, pode-se perceber que as primeiras estão ligadas à linguagem composicional de Guarnieri. Já a peça para viola destaca-se na produção de suas obras de câmera por afastar-se da influência de seu professor em direção a uma linguagem contemporânea própria e pessoal.

Nesta parte do artigo, foram feitos comentários somente sobre duas obras. Porém, com base no levantamento feito para este estudo, é possível notar o vasto e rico universo composicional brasileiro para viola. São obras que vão desde uma formação tradicional - viola solo, viola e piano, viola e orquestra - até uma formação não tradicional: viola e 
sons eletrônicos ou viola e faixas sampleadas. As peças passam por diversas linguagens composicionais: nacionalismo brasileiro, romantismo, neorromantismo, modernismo e poéticas contemporâneas. Esse conjunto de obras da música de concerto brasileira se coloca no panorama da música ocidental como relevante contribuição na expansão do ainda escasso repertório para a viola e na consolidação do instrumento como solista.

\section{A Sonata do Girassol Vermelho}

A Sonata do Girassol Vermelho é a peça mais recente para viola e piano do compositor Harry Crowl. Concluída em 2019, faz parte de um corpo de nove composições de Crowl para o instrumento. Uma delas não foi adicionada à lista, Visões do Paraíso (2016) devido a sua formação para viola e violão, pois somente duos para viola foram listadas. Assim como os outros compositores brasileiros, Crowl escreveu menos obras para viola (8 composições) do que para violino (14 composições). Ainda assim, juntamente com Claudio Santoro, Crowl é o compositor que mais escreveu para viola na música brasileira de concerto.

Cambiata para viola solo (1980/83) foi a primeira obra do compositor para o instrumento. O autor comenta sobre a obra:

$\mathrm{Na}$ época, estudava viola e queria sentir a criação no próprio instrumento. Porém, não desenvolvi técnica suficiente para executá-la. Foi estreada por Ricardo Giannetti em 1990, numa transcrição para violino solo. A versão original para viola foi posteriormente executada por Zoltan Paulinyi, numa viola pomposa (5 cordas), e Darya Filippenko (CROWL, 2020).

É possível entender o número de obras para viola, já que este é o instrumento de Crowl. Seguem cronologicamente as obras para viola de compositor: Ipês para viola e piano (1996); As Impuras Imagens do Dia se Desvanecem para viola solo (1999); Antíteses, concerto para viola pomposa e orquestra (2009); Visões do Paraíso para viola e violão (2016); Solilóquio VII para viola solo (2017); Paisagens Meridionais no.4, para viola, piano e orquestra de cordas (2017); Sonata do Girassol Vermelho para viola e piano (2019).

Referências e inspirações literárias são frequentes na obra de Crowl, assim como na Sonata do Girassol Vermelho, na qual o título está relacionado ao conto literário "A Casa do Girassol Vermelho", do escritor mineiro Murilo Rubião (1916-1991). Pouco conhecido na literatura brasileira, Rubião foi o expoente do realismo fantástico no Brasil 
e um dos poucos representantes desse gênero em língua portuguesa. Seus contos surgiram de forma espontânea no final dos anos 1940 - "sua primeira obra data de 1947" (RUBIÃO, 2016, p. 251) - não tendo ele tido contato com os textos de Franz Kafka (1883-1924) nem estado vinculado a nenhum movimento literário latino-americano. Jorge Schwartz (1944) comenta:

\begin{abstract}
Anterior a Julio Cortázar, que publica os primeiros contos em 1951 (Bestiário), tematicamente se vincula aos escritores de vanguarda hispanoamericanos, os exploradores do chamado "realismo mágico" (Jorge Luis Borges, Julio Cortázar, Juan José Arreola, Gabriel García Márquez etc) (RUBIÃO, 2016, p. 251-252).
\end{abstract}

Rubião era um escritor perfeccionista que trabalhava exaustivamente em seus textos e, por esse motivo, sua obra é pequena e compõe-se de somente 33 contos, gênero ao qual dedicou-se integralmente. Todos esses textos vêm acompanhados de uma epígrafe bíblica. "Rubião foi efetivamente um assíduo leitor da Bíblia, um leitor que aos poucos se descomprometeu do modo de leitura religiosa convencional, para encontrar numa fantasia muito particular de leitura uma fantasia muito particular de escritura" (PERCINO, 2018, p. 220). As epígrafes não apresentam função clara em relação ao texto e por isso abrem espaços para várias interpretações como comenta Percino:

\footnotetext{
O leitor crítico talvez não conceda importância à presença pirotécnica das epígrafes ou talvez se deixe perturbar por elas; mas ficará, de qualquer forma, num interlúdio de indagações, vacilando sobre o sistema de relações entre epígrafes e epígrafes ou epígrafes e narrativas, considerando-as indefinidamente como ornamento, busca de autoridade, referência, espelho temático, síntese, protocolo, efeito-fratura e interrogação (PERCINO, 2018, p. 220).
}

"Vós sois o sal da terra. E se o sal perder a sua força, com que outra coisa se há de salgar?” (Matheus 5:13). Esse conhecido trecho da Bíblia é a epígrafe que precede o conto "A Casa do Girassol Vermelho". O local é um espaço fechado, lugar atrasado, distante do mundo, dentro do qual movem-se os personagens que são, Simeão e Belisária, pais adotivos de dois grupos de irmãos. O pai atua com violência e brutalidade, atitude que parece ser inerente a realidade em que vivem. Após a morte de sua mulher, que protegia os irmãos, Simeão separa os filhos das filhas com a intenção de controlar seus instintos, do ambiente de orgia e perversão sexual existente entre eles. São seres não civilizados e sem limites e a morte do pai por distúrbio cardíaco, significou libertação, sendo festejada com danças. 
As duas únicas referências a espaços externos a essa realidade imutável são a vila onde moravam os casais de irmãos antes de serem adotados. Ao final do texto, um trem passa apitando ao longe, o que faz o narrador refletir: "além de nós, havia no mundo mais alguém” (RUBIÃO, 2016, p.104). Harry Crowl parece ter predileção por temas sombrios e universos paralelos, situações insólitas e personagens solitários. Outra obra de Crowl que liga-se a esse universo é a ópera Sarapalha, sobre texto de Guimarães Rosa (19081967), adaptado por Renata Pallottini. Cevallos comenta sobre a realidade vivida pelo escritor que reflete-se em sua obra literária.

\begin{abstract}
Sarapalha é um dos contos que compõe a obra Sagarana do escritor Guimarães Rosa, importante nome da literatura brasileira. Formado em medicina, o escritor trabalhou na década de 1930 em regiões remotas do sertão mineiro, lugares onde pode escutar relatos e observar a vida, os costumes, a visão de mundo e o linguajar destes lugares onde o tempo custa a passar. Essas experiências são o material com o qual Guimarães Rosa trabalhou para criar seu estilo literário (CEVALLOS, 2012, p. 228).
\end{abstract}

O enredo de Sarapalha passa-se no interior de Minas Gerais e relata a relação dos primos Argemiro e Ribeiro. Após uma epidemia de malária, os primos encontram-se a sós e doentes em uma vila abandonada, em uma situação que os leva ao delírio e à reflexão existencial. Os textos de Rosa e Rubião - escritores mineiros como Crowl - inspiraram o compositor na criação de obras. São narrativas que se passam em um interior no qual o tempo parece ter parado e os personagens encontram-se na condição de prisioneiros dessas realidades. Crowl, no uso dessas temáticas, não faz, em nenhum momento, caricatura do ambiente do interior do Brasil, nem utiliza de forma burlesca a figura do caipira. Pelo contrário, sua música expressa o conteúdo desses textos literários de forma refinada e os regionalismos atuam apenas como cenário para a ação de dramas humanos universais.

Composta por três movimentos, a Sonata do Girassol Vermelho foi dedicada à violista bielorussa Darya Fillipenko (Minsk, 1982) e ao pianista brasileiro Luiz Gustavo de Carvalho (Belo Horizonte, 1982). É pouco comum compositores mencionarem pianistas. Crowl, porém, inclui na dedicatória o músico mineiro, aluno de Eliso Virsaladze (1942) no Conservatório Tchaikovsky em Moscou, solista e camerista de carreira internacional. Com relação à violista, a parceria de Filippenko com Harry Crowl teve início em 2016, após terem sido apresentados em Moscou pelo diplomata brasileiro Wellington Müller Bujokas (1982). Entusiasta da música de concerto brasileira, Bujokas tem organizado concertos nos países onde tem atuado e dessa forma, instrumentistas 
desses lugares tem entrado em contato com a nossa música, incorporando em seus repertórios obras de compositores brasileiros. Após esse contato por meio do diplomata, Filippenko interpreta obras para viola de Harry Crowl, Silvio Ferraz (1959), Lindembergue Cardoso (1939-1989), Almeida Prado, Claudio Santoro, César GuerraPeixe (1914-1993) e Heitor Villa-Lobos (1887-1959).

A partir da organização de concertos realizados por Bujokas em Moscou, a violista interpretou Cambiata e Ipês de Harry Crowl. Após conhecerem-se, o compositor dedicou a ela Visões do Paraíso $^{3}$ para viola e violão, que foi estreada por Filippenko e pelo violonista russo Vladimir Gapontsev (1985). Devido ao interesse da instrumentista pela música brasileira e às interpretações de suas peças anteriores, o compositor decidiu escrever para a violista uma obra substancial e mais elaborada do que quaisquer outras composições que já tivesse escrito para violino e piano ou violoncelo e piano. Dessa forma, surgiu a Sonata do Girassol Vermelho.

\section{Ferramentas Analíticas}

As diversas ferramentas analíticas, amplamente discutidas no Brasil a partir do final do séc. XX/início do séc. XXI, tais como, Janelas Hermenêuticas (L. Kramer), Semiótica (E. Tarasti, K. Agawu), Teoria das Tópicas (R. L. Cano, P. T. Salles, A. Piedade, L. Ratner, R. Monelle, R. Hatten) e Gestos Musicais (N. Dudeque, R. Hatten), possibilitam uma compreensão mais detalhada e aprofundada de uma obra musical.

A análise pode ser realizada com uma ou mais ferramentas. No caso da Sonata, a técnica que parece ser mais adequada para análise é a das "Janelas Hermenêuticas" de Kramer (1946), devido à maneira como o compositor realizou sua criação, ou seja, partiu de um texto literário para depois escrever o texto musical.

O termo, hermenêutica, está ligado à interpretação de livros sagrados e textos antigos, se refere também à interpretação ou compreensão de um texto, dos sentidos e/ou da significação das palavras que o compõem. Seu desenvolvimento deu-se na época áurea da filosofia grega e também através da teologia, mas foi somente com o filósofo Friedrich

\footnotetext{
${ }^{3}$ O título faz uma alusão à obra do historiador e antropólogo Sérgio Buarque de Hollanda (1902-1982), Visão do Paraíso (1959), que trata do deslumbramento dos europeus com as terras e os povos do Novo Mundo (CROWL, 2020).
} 
Schleiermacher (1768-1834) e a reformulação feita por ele, que esta entrou para o universo da filosofia acadêmica. Hartmann Sobrinho comenta:

\begin{abstract}
Schleiermacher determinou a exigência de se estabelecer uma hermenêutica geral traduzida em uma teoria geral da compreensão. Esta hermenêutica geral estabeleceria princípios para toda e qualquer compreensão e interpretação de manifestações linguísticas (HARTMANN SOBRINHO, 2010, p. 69).
\end{abstract}

Alguns musicólogos trouxeram elementos da hermenêutica para os estudos em análise musical. Leonard Meyer (1918-2007) em Emotion and Meaning in Music (1956) "categoriza e classifica diversos aspectos sobre os significados musicais" (HARTMANN SOBRINHO, 2010, p. 70). Anos depois, Joseph Kerman (1924-2014) em Contemplating Music: Challenges to Musicology (1985) propõe "uma nova forma de análise que contemple o conteúdo 'subjetivo' presente no discurso musical" (HARTMANN SOBRINHO, 2010, p. 70). Porém, foram os escritos do musicólogo Lawrence Kramer que consolidaram a hermenêutica como uma ferramenta da análise musical.

O interesse por linguagem se explica, pois Kramer é professor na Universidade de Fordham em Nova York, em dois departamentos: o de inglês e o de música. Em entrevista, ele comenta:

\footnotetext{
A filiação dupla me confere uma identidade profissional que une minhas atividades atuais. Eu, na maior parte do tempo, ensino inglês; eu, na maior parte do tempo, escrevo e componho música. As duas atividades interagem constantemente, dentro e fora da sala de aula (NESTOR, 2020).
}

Kramer tem em seu catálogo, textos que abrangem temas como: teoria da literatura, psicanálise, crítica musicológica, relação texto/música e hermenêutica musical. Esta última, uma ferramenta analítica, pretende a compreensão dos significados musicais inerentes. "Abrir uma janela hermenêutica significa encontrar momento por onde a interpretação poderia passar" (HARTMANN SOBRINHO, 2010, p. 73). Kramer relaciona três janelas hermenêuticas: inclusões textuais, inclusões citacionais e tropos estruturais. 
Inclusões textuais - Este tipo inclui textos musicados, títulos, epigramas, programas, notas na partitura e eventualmente até mesmos sinais de expressão. Ao lidar com estes materiais é relevante lembrar especialmente a respeito dos textos de obras vocais - que eles não estabelecem (autorizam ou fixam) um significado que de certa forma a música reitera, mas apenas convidam o intérprete a encontrar significado na interação com os atos expressivos. A mesma observação se aplica aos outros dois tipos (KRAMER, 1996, p. 9, tradução nossa). ${ }^{4}$

Esta primeira janela não se relaciona com a análise que será feita neste estudo, pois a Sonata do Girassol Vermelho é uma obra instrumental. Ao contrário das próximas duas janelas que serão utilizadas.

Inclusões Citacionais - Este é um tipo menos explícito do que o primeiro sendo uma versão deste, pois parte deles se sobrepõem. Inclui títulos que associam uma obra musical com uma obra literária, imagem visual, lugar ou momento histórico, alusão a outros compositores, alusão a outros textos através de alguma citação na música a ele associada; alusão à estilos de outros compositores ou de períodos antigos e a inclusão (ou paródia) de outro estilo característico não predominante na obra em questão (KRAMER, 1996, p. 9, tradução nossa). ${ }^{5}$

Inclusões Citacionais é uma das janelas que será amplamente utilizada na análise, pois o processo de composição de Crowl envolve menções e referências. A terceira janela, “Tropos Estruturais atravessam as distinções tradicionais entre forma e conteúdo. Eles podem emergir a partir de qualquer aspecto da troca comunicativa: estilo, retórica, representação e assim por diante” (KRAMER, 1996, p. 9, tradução nossa) ${ }^{6}$. Esta janela também será utilizada.

\footnotetext{
${ }^{4}$ No original: "Textual Inclusions. This type includes texts set to music, titles, epigrams, programs, notes on the score, and sometimes even expression markings. In dealing with these materials, it is critical to remember - especially with the texts of vocal pieces - that they do not establish (authorize, fix) a meaning that the music somehow reiterates, but only invite the interpreter to find meaning in the interplay of expressive acts. The same caution applies to the other two types."

5 No original: "Citational Inclusions. This type is a less explicit version of the first, with which it partly overlaps. It includes titles that link a work of music with a literary work, visual image, place or historical moment; musical allusions to other compositions; allusions to the text through the quotation of associated music; allusions to the styles of other composers or of earlier periods; and the inclusion (or parody) of other characteristic styles not predominant in the work at hand.

${ }^{6}$ Structural Tropes cut across traditional distinctions between form and content. They can evolve from any aspect of communicative exchange: style, rhetoric, representations, and so on."
} 


\section{Análise de obra}

Quando um compositor emprega no título a palavra sonata, ele liga-se diretamente à tradição desse termo na história da música. No caso dessa obra específica, o compositor comenta "dei o título de sonata para dar mais peso à obra, pois eu planejava algo grande e ambicioso, maior e mais denso do que qualquer coisa escrita para viola no Brasil" (CROWL, 2020). Contudo, não estamos frente a uma obra nos moldes de uma sonata clássica. A composição de Crowl relaciona-se com o momento do surgimento do termo, no final da Renascença, que em italiano significa "aquilo que soa". A ascensão da música instrumental nesse período viu o desenvolvimento de novos gêneros, como variação, prelúdio, fantasia, toccata, ricercare, canzona e sonata. Giovanni Gabrieli (1555-1612) foi um dos importantes compositores do final da Renascença que ajudou a consolidar o que eles conheciam como "sonata veneziana", composta de séries de seções baseadas em diferentes temas.

No primeiro movimento da Sonata, Crowl trabalha com esse conceito da sonata veneziana de variação contínua e contrastes de afetos. A organização do material musical não está ligada à forma sonata, pois o compositor nunca repete temas, ou o faz raramente e de forma inesperada. Essas variações contínuas também podem estar relacionadas com os motetos do séc. XVI e XVII que não repetiam motivos, pois as linhas que formavam a polifonia tinham que seguir o texto que por sua vez, também não era repetido. 
Figura 3 - H. Crowl: Excerto do primeiro movimento da Sonata do Girassol Vermelho (c. 1-6).

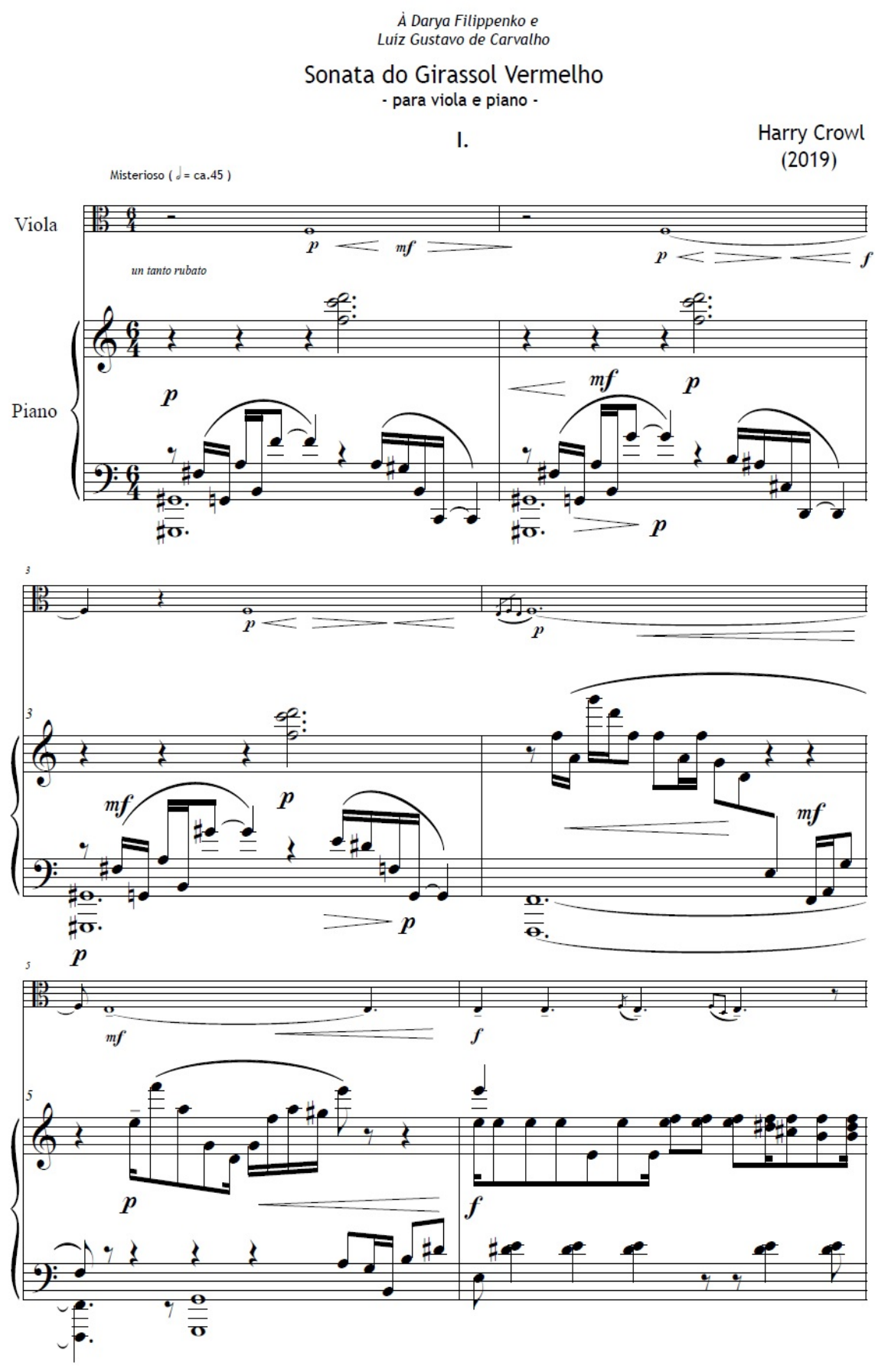

Fonte: CROWL, Harry. Sonata do Girassol Vermelho. Curitiba: pdf/manuscrito do compositor, 2019. Viola e piano.

A Sonata como um todo relaciona-se com esses conceitos do Renascimento e Barroco de maneira abstrata, pois esta foi composta em uma linguagem musical contemporânea e em um discurso muito pessoal (Fig. 3). Crowl comenta sobre sua escrita musical: 
[...] utilizo um discurso atonal na maior parte do tempo, mas às vezes faço incursões em tons específicos e modos litúrgicos. O trabalho com o timbre é muito importante para mim assim como a pesquisa da sonoridade dos acordes. Apesar desse discurso atonal, muitas vezes originário de uma série, evito elementos comuns a semiosfera serial, como o uso de pontilhismos. Toda a minha música tem um conteúdo dramático intencional e que segue um discurso não linear que foge de qualquer forma antiga pré-determinada. Quando uso formas musicais acabo inventando as minhas próprias [...] (BUJOKAS, 2018, p. 110).

Este primeiro movimento é o mais longo (12') e é uma obra em si, mesmo que não fosse acompanhada de outros dois movimentos. Portanto, já seria uma peça relevante para viola na música contemporânea brasileira. Essa percepção apoia-se no fato de que todo o material da viola é o mesmo que o primeiro movimento de Visões do Paraíso, ou seja, já era uma obra anterior. (Fig. 4)

Figura 4 - H. Crowl: Excerto do primeiro movimento de Visões do Paraíso (compassos 1-6). Demonstração do mesmo material na viola com acompanhamento de violão.

à Darya Filippenko

\section{-Visões do Paraíso -}

I.

Contemplativo $\downarrow=$ ca.50

Viola

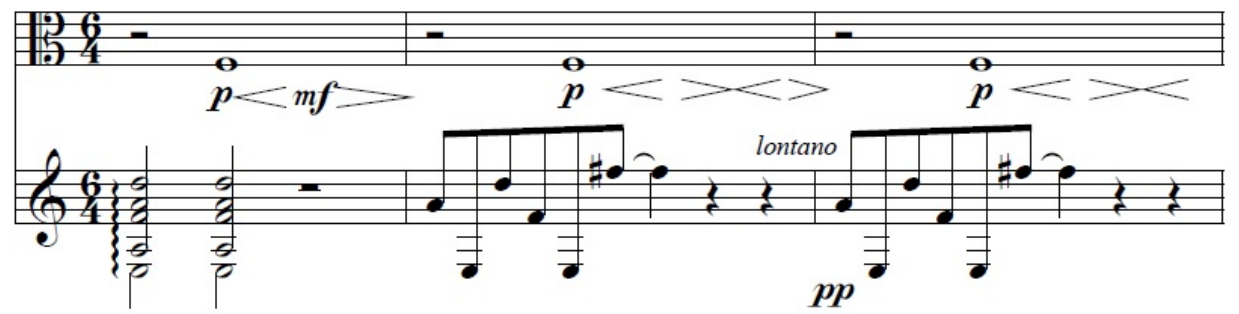

Vla.

$p$

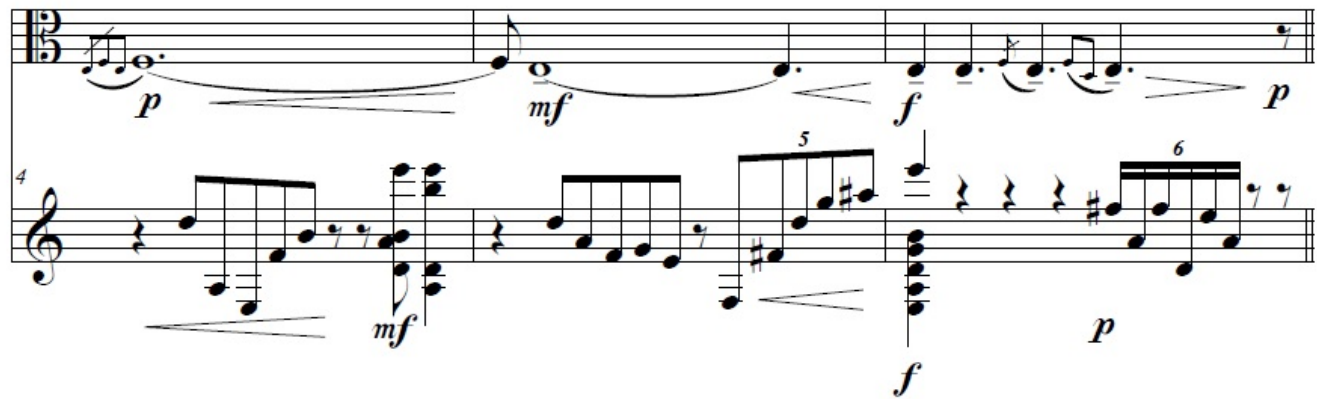

Fonte: CROWL, Harry. Visões do Paraíso. Curitiba: pdf/manuscrito do compositor, 2016. Viola e violão.

O compositor comenta sobre essa escolha composicional "A Darya tocou tão bem e se identificou tanto com a Visões do Paraíso que quis reaproveitar o material, que é todo construído a partir de correspondências entre letras e notas, pela notação alemã, do 
nome dela" (CROWL, 2020). A recontextualização da parte da viola com um acompanhamento de piano, completamente diferente do da peça anterior, cria uma nova obra e somente com um confronto das partituras é possível perceber que é o mesmo material composicional.

Se no momento da audição dessa parte da sonata o ouvinte tiver lido o conto de Rubião, poderá claramente perceber como Crowl constrói musicalmente o ambiente de tensão constante e conflitos diversos apresentados pelo escritor, como: repressão sexual, relações disfuncionais, violência do pai, ausência da mãe, sentimento de abandono, dentre outros. O movimento representa, do ponto de vista não musical, o sistema que levou tempo para formar-se e que tem um processo interno autodestrutivo.

O primeiro movimento não apresenta epígrafe como nos contos de Rubião. O compositor deixou em aberto essa questão para uma escuta livre. Já o segundo movimento vem acompanhado de um título, cujo seu significado e a composição estão diretamente interligados. A sentença, In girumimusnocte et consumimurigni (Aos giros passamos a noite em volta do fogo e somos consumidos por ele) é ao mesmo tempo a epígrafe dessa parte da sonata e um palíndromo ${ }^{7}$. A frase do conto "dançamos, cantamos até a noite nos encontrar exaustos" (RUBIÃO, 2016, p. 102) parece estar diretamente relacionada com a epígrafe.

Esse movimento representa a parte do conto em que os irmãos comemoram a morte de Simeão, o personagem que controla os instintos e a natureza interna humana, símbolo da autoridade paterna e da repressão. Após o óbito, o narrador (irmão Surubi) comenta: "todos nós fôramos tocados por uma centelha diabólica, que nos fazia buscar, ansiosos, no prazer, o esquecimento dos dias de desespero do passado" (RUBIÃO, 2016, p. 98). Nesse primeiro momento de liberdade, é possível perceber como os irmãos são seres primitivos e rústicos, em sua busca de conforto na satisfação de seus instintos. Assim, iniciam uma festa, a única forma de celebração que eles conheciam: "todos os acontecimentos alegres da nossa existência eram comemorados com bailados coletivos" (RUBIÃO, 2016, p. 100).

\footnotetext{
${ }^{7}$ Diz-se de palavras, números ou frases que se podem ler indiferentemente da esquerda para direita e vice e versa, sempre com o mesmo sentido.
} 
A violência não cessa com a morte do pai. Imersos nessa sensação de delírio, uma das primeiras coisas que os irmãos homens fazem é amarrar a mulher que cuida das meninas e liquidar o "preto fortíssimo" (RUBIÃO, 2016, p. 101) que andava armado e acompanhava Simeão, ou seja, eles desejavam acabar com tudo que estava ligado ao pai. O falecimento do pai significaria a derrubada do sistema opressor. Porém após os momentos de frenesi, os irmãos dão-se conta de que era a figura de Simeão (e tudo que ele representava) que dava razão à existência deles que agora encontram-se jogados à própria sorte, como comenta o narrador do conto:

Sabíamos que nada mais seria importante, digno da violência, da paixão. Um futuro mesquinho nos aguardava: Belsie se amarraria a um agressivo mutismo. Marialice e Nanico - dois idiotas - olhariam um para o outro indefinidamente, alheios a qualquer determinação de romper com o mundo. Belinha, sem os apelos do irmão, não sentiria explodir a carne e guardaria para si os frutos da fecundação. Eu, gigante bronco, viveria de braços caídos. (RUBIÃO, 2016, p. 103-104).

Essa situação tem relação com o uso do palíndromo: seu emprego no título desse movimento refere-se a saída de um local e a volta ao mesmo. Nesse caso, o movimento de ida, seriam todos os acontecimentos que levam à morte de Simeão. Já o movimento de volta, à tomada de consciência, por parte dos irmãos, de que sem o pai sua existência já não tinha sentido, ou seja: não os levou a lugar nenhum. A prática de Rubião de utilizar frases antes dos contos é aqui utilizada por Crowl. Todavia, o compositor insere dentro desse conceito de epígrafe algo distinto e com significado próprio que é o palíndromo.

O primeiro movimento ambienta o universo do conto como um todo. No segundo, é possível sentir o foco do compositor na representação do delírio dos personagens com a morte de Simeão e a derrubada do sistema empregado por ele. O movimento é composto por duas partes: a primeira representa musicalmente a ida do palíndromo (compassos $1 \mathrm{a}$ 123) (Fig. 5). Nessa primeira parte, é possível reconhecer dois momentos distintos: do início até o compasso 52, há o predomínio da textura em uníssono e oitavas entre a viola e o piano no uso de frases de colcheias em legato, contrastando com acordes acentuados também em uníssono. Há a mudança de afeto, com o emprego de notas longas (compassos 53 a 59), e o início de um segundo momento com o emprego do mesmo material do primeiro, entretanto, aqui já não mais em uníssono, mas com melodia acompanhada, tendo a alternância das colcheias, semicolcheias e acordes ora na viola, ora no piano. 
Figura 5 - H. Crowl: Excerto do segundo movimento da Sonata do Girassol Vermelho (c 53-58). Demonstração da ida do palíndromo.

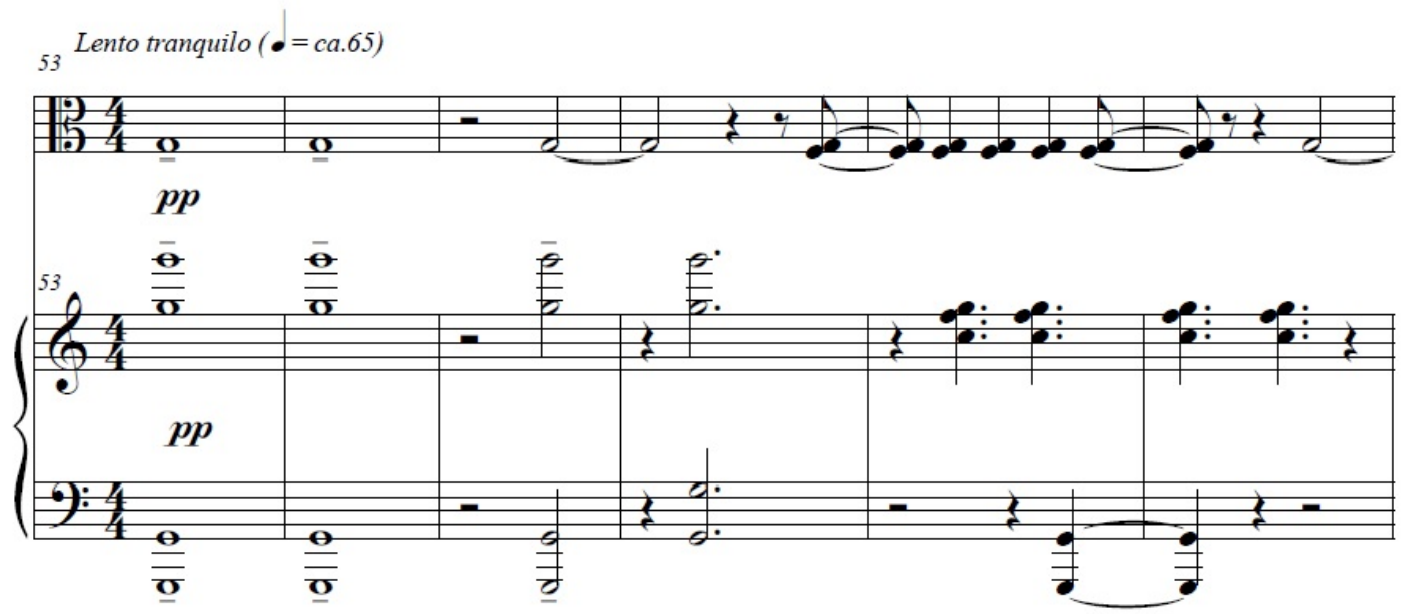

Fonte: CROWL, Harry. Sonata do Girassol Vermelho. Curitiba: pdf/manuscrito do compositor,2019. Viola e piano.

A segunda parte (c. 124-236) combina as texturas em uníssono e em melodia acompanhada apresentadas anteriormente. Além disso, o compositor consegue dar musicalmente a sensação de estarmos ouvindo o mesmo material musical de trás pra frente, ou seja, a volta do palíndromo. (Fig. 6)

Figura 6 - H. Crowl: Excerto do segundo movimento da Sonata do Girassol Vermelho (c. 125-130). Demonstração da volta do palíndromo.

${ }_{53}$ Lento tranquilo $(\bullet=$ ca.65)

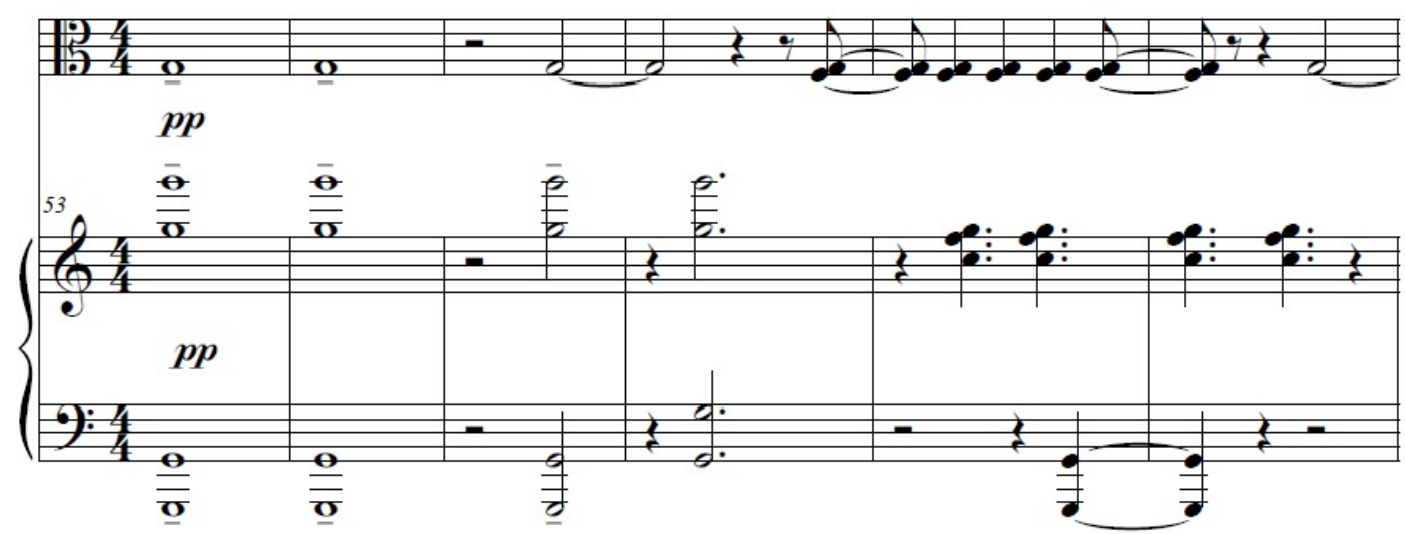

Fonte: CROWL, Harry. Sonata do Girassol Vermelho. Curitiba: pdf/manuscrito do compositor,2019. Viola e piano.

Todo este movimento é em andamento rápido e marcado por mudanças constantes de métrica $(5 / 8,3 / 8,2 / 8,3 / 8,4 / 4,12 / 8,2 / 4)$, o que caracteriza o emprego de ritmos 
irregulares. As frases de colcheias e semicolcheias fazem referência à dança frenética dos irmãos que vivem em um estado primitivo de desenvolvimento. E os acordes estão ligados com a violência presente em vários momentos do conto.

O terceiro e último movimento da Sonata, iniciado com a epígrafe "Aqui ficaremos, um ano, dez, cem ou mil”, refere-se claramente ao estado de imutabilidade e isolamento dentro do qual vivem os personagens do conto. Eles só terão consciência de sua situação quando algo inesperado ocorre no final do conto. "Um trem apitou ao longe e, ao passar por nós, deixou uma esteira de fagulhas. Dos carros, que seguiam velozes, saltavam quadradinhos prateados. Cheios de gente. Além de nós, havia no mundo mais alguém” (RUBIÃO, 2016, p. 104). Somente quando esses veículos aparecem, é que os irmãos se dão conta da existência de vida para além da 'Casa do Girassol Vermelho'. Entretanto, o conhecimento de que não estão a sós no mundo não lhes serve de nada, pois não foram preparados para viver naquele outro mundo: o da civilização.

Há uma tentativa de interação com esse mundo, por parte do narrador (o irmão Surubi), mas ela é feita à maneira dos irmãos: de forma agressiva e na tentativa de sublimar a figura de Simeão.

\footnotetext{
Era preciso reagir. Avancei resoluto pela estrada e, atravessando na frente dos companheiros, exigi que parassem. Firme, os punhos cerrados, conclamei todos para a luta, que seria contra sombra do velho Simeão. Tracei planos para a campanha, ameacei e gritei. Aos poucos minha voz foi amortecendo. Olhavam-me mudos, os rostos sem esperança. (Xixiu morrera mesmo.) Dei-me por vencido. Não adiantava lutar. Tudo se quebrara (RUBIÃO, 2016, p. 104).
}

Surubi desiste de tentar ao perceber que não há mais nada o que fazer. O conto termina com uma imensa sensação de abandono e desolação. Musicalmente, o movimento inicia-se com figura rápida em fusas no piano que se repetem constantemente e não saem do lugar, tendo na viola notas longas e contemplativas (c. 1-24), alusão à invariabilidade e à solidão. Esse tipo de textura é algo recorrente na obra de Crowl. O compositor deixa uma nota ou acorde em sustentação, enquanto a outra voz realiza movimentadas variações em paralelo.

A parte interna do movimento (c. 25-97) é uma conversa entre os instrumentos. O material musical do piano mantém-se com figuras em fusas, alternando com acordes, e na viola segue a predominância das notas longas. Essa tentativa de diálogo e 
entendimento não é bem-sucedida - assim como no conto. Os últimos compassos do movimento (c. 98-132) apresentam caixas de repetição na viola com o efeito de sul ponticello e sul tasto que funcionam bem na descrição do ambiente de angústia e conflito presentes no conto, é também a coda da Sonata em que aparecem elementos do primeiro movimento (Fig. 7).
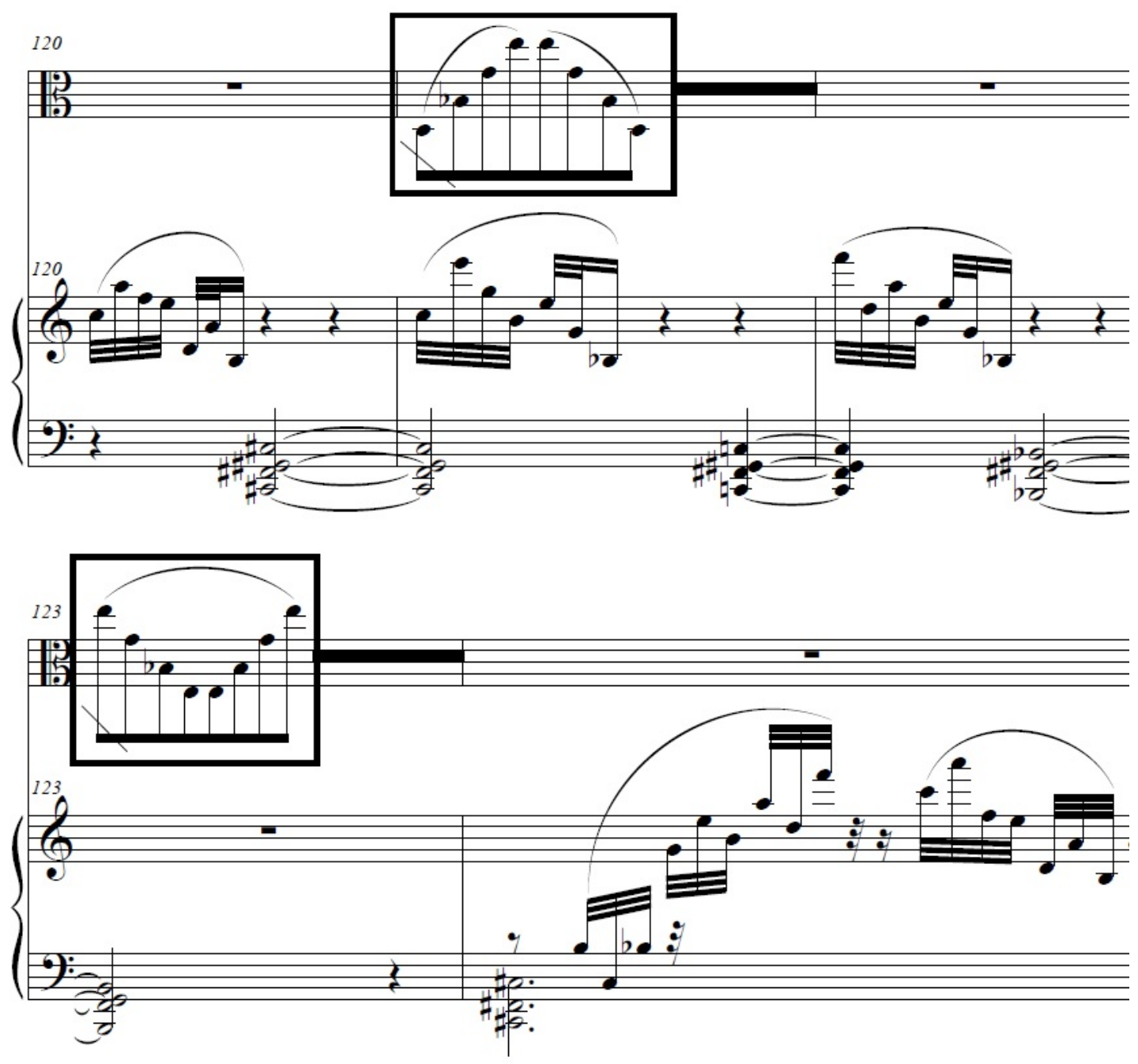

Fonte: CROWL, Harry. Sonata do Girassol Vermelho. Curitiba: pdf/manuscrito do compositor, 2019. Viola e piano. 
Esta terceira parte da sonata apresenta a tensão entre dois planos: o dinâmico, que é o dos veículos, e o estático, que é o da civilização contra o mundo dos irmãos e todas as características que o compõem.

\section{Conclusão}

Darya Filippenko e Ksenia Apalko estrearam a Sonata do Girassol Vermelho, em Moscou, em maio de 2019. Mais adiante, Darya Filippenko e Luiz Gustavo Carvalho apresentaram-se em turnê pelo Brasil no mês de setembro do mesmo ano, nas cidades de Tiradentes, Belo Horizonte, Campinas e Curitiba, sendo que nesta última tiveram a oportunidade de gravar a Sonata.

A linguagem empregada por Crowl na escrita da Sonata do Girassol Vermelho demonstra que a música para viola, no séc. XXI, em nada fica a dever para o repertório de violino, ou de violoncelo, e que o instrumento ainda tem muitas possibilidades a oferecer, mesmo numa linguagem mais idiomática que não extrapole para um uso excessivo de técnicas estendidas. A música de câmera escrita no Brasil tem mostrado cada vez mais uma diversidade de técnicas, linguagens e criatividade por parte dos compositores, apesar do espaço ainda restrito para a sua divulgação. 


\section{Referências}

BUJOKAS, Wellington M. Reflexões sobre a criação musical: Entrevista com Harry Crowl. Tom Caderno de Ensaios, Curitiba, v.4, n.8, dezembro, 2018.

CEVALLOS. Semitha H. M. A ópera Sarapalha do compositor brasileiro Harry Crowl. Atas do Congresso Internacional A língua Portuguesa em Música, Lisboa, 2012.

CROWL, Harry. Obras para viola de Harry Crowl. [mensagem pessoal]. Mensagem recebida por spianista@gmail.com em 20 mai.2020.

CROWL, Harry. Sonata do Girassol Vermelho. Curitiba: pdf/manuscrito do compositor,2019. Viola e piano.

CROWL, Harry. Visões do Paraíso. Curitiba: pdf/manuscrito do compositor,2016. Viola e violão.

GUARNIERI, Camargo. Sonata para viola e piano. São Paulo: manuscrito, 1950. Viola e piano.

HARTMANN SOBRINHO, Ernesto Frederico. Estética musical e realismo socialista em obras nacionalistas para piano de Claudio Santoro: janelas hermenêuticas. 2010. Tese (Doutorado em Música) - Programa de Pós-graduação em Música, Universidade Federal do Estado do Rio de Janeiro, Rio de Janeiro.

KRAMER, Lawrence. Classical Music and Post-Modern Knowledge. Los Angeles: University of California Press, 1996.

MIZAEL, Hellen Dias. Sonata para viola e piano (1950) de Camargo Guarnieri: estudo técnico interpretativo e tratamento editorial. 2011. Dissertação (Mestrado em Música) - Programa de Pós-graduação em Música, Universidade Federal de Minas Gerais, Belo Horizonte.

NESTOR, Emer. The Man Behind the Musicology: Lawrence Kramer. In: Final Note Magazine Home Page. Disponível em http://finalnotemagazine.com/articles/lawrence-kramer. Acesso em: 22 nov. 2020.

PERCINO, Ezequiel B. Epígrafes Bíblicas em Murilo Rubião. Fronteira Z, São Paulo, n. 20, julho, 2018.

PRADO, Almeida. Sonata para viola e piano. Rio de Janeiro: Academia Brasileira de Música Banco de Partituras de Música Brasileira, 2011. Viola e piano.

PRIMROSE, William. Walk on the North Side: Memoirs of a Violist. Provo, Utah: Brigham Young University Press, 1978.

RILEY, Maurice W. The History of the Viola. Ann Arbor: Braun-Brumfield, 1980.

RUBIÃO, Murilo. Murilo Rubião: obra completa. São Paulo: Companhia das Letras, 2016.

SANTORO, Alessandro. A Sonata para viola e piano de Claudio Santoro. [mensagem pessoal]. Mensagem recebida por spianista@hotmail.com em 02 mai. 2020.

VALLE, Raul do. Raul do Valle: catálogo de obras. Organização Valeria Peixoto. Rio de Janeiro: ABM, 2016. 


\section{Apêndice}

Quadro 1 - Obras Brasileiras para Viola.

$O B R A$

Sonata $n^{\circ} 1$ (1943) obra perdida

Sonata para viola e piano (1950)

Três peças para viola e piano (1957)

Brasiliana para viola e piano (1960)

Sonata para viola e piano (1962)

Sonata para viola e piano (1962)

Sonata opus 11 para viola solo (1963)

Adágio para viola e piano (1965)

Chorinho (1965)

O lago - fantasia, para viola e piano (1965)

Espaços para viola e piano (1966)

Viola I (1966)

Desafio I para viola e orquestra de cordas (1968)

Desafio II para viola e piano (1968)

Sonata para viola e piano (1968)

Três Valsas Brasileiras para viola e piano (1968)

Fantasia para viola e piano (data ignorada)

Sonata para viola e piano (1969)

Sonata para viola e piano (1969)

Concertino para viola e orquestra (1969)

Microformóbiles I (1970)

Concerto para viola e orquestra (1970)

Mutationen IV para viola e fita magnética (1971/72)

Serenata para viola e piano (1974)

Mobile I para viola e piano, op.85 (1973/75)

Choro para viola e orquestra (1975)

Mascaruncho para duas violas (1975)

Sonatina para viola e piano (1976)

Estrias I para viola solo (1976)

Apassionato, cantilena e tocata para viola e piano (1977)

Sertões para viola solo (1978)

Concertino para viola e cordas (1978)

Sonata para viola e piano (1978)

Cinq Petites Pièces para duas violas (1979)

Tango para viola e piano (1980) Mutações (1980)

As Melodias da Cecília para viola e piano (1982)

Sonata $n^{\circ} 2$ para viola e piano (1982)

Variações a Berg para viola solo (1982)

Pequeno Estudo para viola solo, op.78 (1982)

Sonata para viola e piano (1983)

Entretenimentos $n^{\circ} 2$ para viola e orquestra de cordas (1983)

Fantasieta para viola solo (1983)

Cambiata para viola solo (1980/83)

Fantasia Sul América para viola solo (1983)

Fantasia Sul América para viola e orquestra

(1983)

Bilhete de um jogral para viola solo (1983)

\section{COMPOSITOR}

Claudio Santoro

Camargo Guarnieri

Cesar Guerra-Peixe

Edino Krieger

Francisco Mignone

Osvaldo Lacerda

Marlos Nobre

Claudio Santoro

João de Souza Lima

Lycia de Biase Bidart

Claudio Santoro

Frederico Richter

Marlos Nobre

Marlos Nobre

Ernst Mahle

Francisco Mignone

Francisco Mignone

Radamés Gnatalli

Edmundo Villani-Cortês

José Siqueira

Jorge Antunes

Radamés Gnatalli

Claudio Santoro

Lycia de Biase Bidart

Ernst Widmer

Camargo Guarnieri

Jorge Antunes

Ernst Mahle

Raul do Valle

Osvaldo Lacerda

Almeida Prado

Ernst Mahle

Breno Blauth

Jorge Antunes

Emilio Terraza

Raul do Valle

Ernst Mahle

Claudio Santoro

Flo Menezes

Lindembergue Cardoso

Almeida Prado

Andersen Viana

Andersen Viana

Harry Crowl

Claudio Santoro

Claudio Santoro

Cesar Guerra-Peixe 
Alternâncias para viola e orquestra de cordas

(1983)

Fantasieta para viola e piano (1984)

Réquiem para a paz sobre fragmentos do Réquiem de Mozart para viola e piano (1985)

Tocata para viola e piano (1985)

Sonatina para viola solo (1985)

Meloritmias $n^{\circ} 5$ (1987)

Concerto para viola e orquestra (1987)

Concerto $n^{\circ} 1$ para viola e orquestra (1988)

Concerto para viola e orquestra (1988)

Concertino para viola e orquestra de cordas (1989)

Duos Modais para duas violas (1991)

Trugklang para viola e eletrônica (1993)

Sonatina para viola e piano (1994)

Alkaest para três violas (1994)

Suite II - A Natureza para septeto de violas

(1995)

Prelúdio e Tango para viola e piano (1995)

Bridges para viola solo (1995)

L'épreuve Du Labyrinthe para viola e faixas sampleadas (1996)

Ipês (1996)

Confronto $n^{\circ} 1$ para duas violas (1997)

Fantasia para viola solo (1998)

As impuras imagens do dia se desvanecem para viola solo (1999)

Confronto $n^{\circ} 2$ para duas violas (2001)

Seresta $n^{\circ} 3$ para viola e piano (2001)

Il Lamento para viola solo (2001)

Perfurando a Linha (2002)

Poema II opus 94 n² para viola e piano (2002)

Canções Avulsas para viola e piano (2002)

Cantilena para viola solo (2003)

Cantilena para viola e piano (2003)

Seresta para viola e piano (2003)

Concerto para viola e orquestra de câmara (2004

Momentos para viola e piano (2004)

Eindrücke para viola solo (2004)

Xilogravura para viola e piano (2004)

Purifying para duo de violas (2006)

Concerto para viola e orquestra (2007)

Todas as Rosas são brancas para viola e orquestra de cordas (2008)

Antiteses para viola pomposa e orquestra (2009)

Karikaturas para duo de violas (2010)

Concertâncias $n^{\circ} 1$ para viola e orquestra (2010)

Concertâncias $n^{\circ} 2$ para viola e orquestra (2010)

Música Precisa para viola solo (2010)

Micropeças para viola solo (2011)

Nouer IV para viola e piano (2011)

Time Wheel para viola e sons eletrônicos ao vivo

Intarsia para viola e sons eletrônicos

(2011/2012)

Ruínas onde nunca estarei para viola solo (2012)
Raul do Valle

Andersen Viana

Almeida Prado

Ricardo Tacuchian

Mario Ficarelli

Ernani Aguiar

Marcos Padilha

Claudio Santoro

Mário Tavares

João Guilherme Ripper

Ernest Mahle

Igor Lintz Maues

José Orlando Alves

Roberto Victório

Roberto Victório

Wellington Gomes

Arthur Kampela

Aldo Brizzi

Harry Crowl

Jailton de Oliveira

Jailton de Oliveira

Harry Crowl

Jailton de Oliveira

Liduíno Pitombeira

Marcos Padilha

Edson Zampronha

Marlos Nobre

Nestor de Hollanda Cavalcanti

Andersen Viana

Sérgio de Vasconcellos-Corrêa

Sérgio de Vasconcellos-Corrêa

Alexandre Eisenberg

Jailton de Oliveira

Maury Buchala Filho

Ricardo Tacuchian

Felipe de Almeida Ribeiro

Antônio Carlos Borges Cunha

Guilherme Nascimento

Harry Crowl

Azael Neto

Jailton de Oliveira

Jailton de Oliveira

Sérgio Roberto de Oliveira

Andersen Viana

Eli-Eri Moura

Paulo Chagas

Tatiana Catanzaro

Felipe de Almeida Ribeiro 
Pontos e linhas, entre planos para viola solo

(2012)

Concerto para viola e cordas (2012)

Estudos sobre os estados da matéria para viola solo (2012)

Partita para viola solo (2012/2013) Aluir para viola solo (2013)

Semplissances $n^{\circ} 1$ para viola solo (2013)

Concerto para viola e orquestra $n^{\circ} 1$ (2013)

Concerto para viola e orquestra $n^{\circ} 2$ (2013)

Micropeças para viola e piano (2014)

Tafetá para viola solo (2014)

Concerto para viola e orquestra (2014)

Sonata para viola e piano (2015)

O Catraz II, engenhoca para viola solo (2015)

Concerto para viola e orquestra (2015)

Tomilho para viola e piano (2015)

Toccata para duas violas (2016)

Poem to an Ancient Tree para viola solo (2016)

Scherzo Pastorale para quarteto de violas (2018)

Cinco miniaturas para viola e piano (2018)

Solilóquio VII para viola solo (2017)

Paisagens Meridionais $n^{\circ} 4$ para viola, piano e orquestra de cordas (2017)

Manun ad Manun para viola solo (2019)

Moviola para viola solo (2019)

Três Prelúdios para viola solo (2019)

Sonata do Girassol Vermelho para viola e piano

(2019)

Enceladus para viola solo (2019)

Brasil, 1959 (uma seresta para Villa) para viola e piano (2019)

Diálogo para viola solo (2019)

Verge para viola solo (2019)

The sorrows of a blindwater-carrier para viola solo (2020)

Suite Brasileira para viola solo (2020)

Tentos sobre um Miserere para viola solo (2020)
CEVALLOS, Semitha Heloise Matos. A Sonata do Girassol Vermelho:

contribuições para a literatura musical para viola, p. 193-222.

Recebido em 26/09/2020; aprovado em 25/11/2020
Rodolfo Coelho de Souza

Vagner Cunha

Valeria Bonafé

Marcílio Onofre

Azael Neto

Jailton de Oliveira

Liduíno Pitombeira

Liduíno Pitombeira

Andersen Viana

Gustavo Cardoso Bonin

José Orlando Alves

André Mehmari

Daniel Vargas

Ernst Mahle

Ricardo Tacuchian

Acácio Piedade

Lourdes Saraiva

Leonardo Martinelli

Ricardo Tacuchian

Harry Crowl

Harry Crowl

Alexandre Lunsqui

Alexandre Lunsqui

Eduardo Frigatti

Harry Crowl

Jocy de Oliveira

Ilza Nogueira

Marisa Rezende

Silvia de Lucca

Antonio Celso Ribeiro

Dimitri Cervo

Harry Crowl 
